\title{
Effect of Board Management and Governmental Model on Zakat Payers' Trust on Zakat Institutions
}

\author{
Erlane K Ghani (Corresponding Author) \\ Accounting Research Institute, Universiti Teknologi MARA, Malaysia \\ Tel: +60162388429 Email: erlanekg@salam.uitm.edu.my \\ Asmah Abdul Aziz \\ Faculty of Accountancy, Universiti Teknologi MARA, Malaysia \\ Tel: +6014332969 Email: asmah030@salam.uitm.edu.my \\ Sakinah Mohamed Tajularifin \\ Faculty of Accountancy, Universiti Teknologi MARA, Malaysia \\ Tel:+60132229342 Email: sakinah_0403@yahoo.com \\ Nahla Samargandi \\ Faculty of Economics and Management, King AbdulAziz University, Saudi Arabia \\ Tel: +966555512633 Email: nahlasamargandi@gmail.com
}

\begin{abstract}
Trust among zakat payers is important as it contributes to the success of zakat institutions. Zakat payers, are reluctant to pay zakat through zakat institutions due to lack of trust. This study examines whether perceived board management and governmental model may influence zakat payers' trust on zakat institutions. Using questionnaire survey on 184 zakat payers, this study shows that perceived board management influences zakat payers' trust on zakat institutions. By contrast, perceived governmental model does not influence zakat payers' trust on zakat institutions. These findings imply that zakat institutions should focus on strengthening the efficiency of their institutions to increase the trust level among zakat payers. In doing so, the zakat payers are driven to pay zakat diligently, thereby ensuring the sustainability of zakat institutions particularly in developing countries such as Malaysia.
\end{abstract}

Keywords: zakat payers, trust level, board management, governmental model, zakat institutions.

\section{Introduction}

In Malaysia, the government has established zakat institutions to administer zakat. Administrating zakat is important to ensure that its collection and distribution is conducted effectively. Zakat institutions also play a role in providing guidelines and explanations on the importance of zakat to strengthen the conscience of the Muslims. Despite the efforts of zakat institutions to encourage eligible Muslims to pay zakat formally, the amount of zakat collection to date remains relatively small (Ahmad \& Ma'in, 2014). This low number leads to concerns on why this scenario exists.

One of the reasons leading to this scenario is the lack of trust among zakat payers, which results in non-compliance behavior (Ahmad \& Ma'in, 2014). Studies show that trust among zakat payers contributes to the success of zakat institutions. The perception of the zakat payers on the efficiency of zakat institutions may influence the payers' trust on the institutions (Salleh, 2006). Mohammad (1990) found that since the government of Pakistan has introduced compulsory zakat collections through formal zakat institutions, trust among zakat payers 
remains the survival factor for such institutions. Zakat payers tend not to pay zakat through formal institutions because they believe that the institutions are untrustworthy (Mohammad, 1990). Zakat institutions must understand the determinants influencing the zakat payers' trust. Doing so can lead to the future development and sustainability of zakat institutions (Abioyea, Mohamad, \& Adnan, 2011; Abdul Rahman, et al, 2016).

This study examines the factors influencing zakat payers' trust on zakat institutions. Specifically, this study examines the influence of perceived board management and governmental model on zakat payers' trust on zakat institutions. The findings in this study can assist zakat institutions to increase the trust level of zakat payers on them and consequently improve zakat collections. The remainder of this paper is structured as follows. The next section reviews the related literature. The following section presents the research framework and hypotheses of this study. The subsequent section outlines the research methodology, followed by the results and discussions. The final section concludes this study.

\section{Literature Review}

Zakat is one of the five fundamental pillars of Islam categorized under obligatory charity (Rahman, Alias, \& Omar, 2012). The Shariah refers to zakat as a redistribution of wealth to the deserving category of people (Rahim \& Kaswadi, 2014, p. 352). The main purpose of zakat is to improve the socio-economic status of individual asnafs (zakat recipients) the and the economy of the nation as a whole (Othman, Ahmad, \& Salleh, 2015). Zakat is perceived as an alternative means to reduce poverty and improve the quality of life among zakat recipients (Abdul Rahman, Al Smady, \& Kazemian, 2015; Nadzri, Rahman, \& Omar, 2012). If zakat collection is managed efficiently, then it can positively affect the socio-economic of the asnafs. However, studies show that zakat payers tend not to pay zakat through formal institutions (e.g., zakat institutions) because they believe that these institutions are untrustworthy.

Bennett and Barkensjo (2005) noted that trust in a non-profit context occurs when a trusting party believes that the trusted party will fulfill the given obligations, and the fulfillment should be satisfied by the trusting party. Trust promotes cooperative behavior, reduces uncertainty and risk in people's relationship, decreases transaction costs, and facilitates formation of ad-hoc work groups (Doney \& Cannon, 1997; Meyerson, Weick, \& Kramer, 1996). Given that the effectiveness of zakat institutions is highly dependent on zakat payers' support, understanding the factors influencing trust among zakat payers is imperative.

\section{Board Management}

One of the possible factors of trust is board management. Zakat payers expect the board management to demonstrate competence, effectiveness, and fairness in their relationship with all stakeholders, including zakat beneficiaries (Mustafa, Mohamad, \& Adnan, 2013). Therefore, the zakat management should clearly understand the role of board management as a vital component in organizational resource management. Mainly, board management plays four critical roles, namely, monitoring, service, strategy, and resource provision (Daily, Dalton, \& Rajagopalan, 2003; Ong \& Wan, 2008; Zahra \& Pearce, 1989).

Salleh (2014) reported that despite the substantial accomplishment of zakat institutions, those in Malaysia face two main obstacles. The first obstacle is the structural autonomy; zakat centers are under the auspices of the State Islamic Religious Council (SIRC). Zakat centers are accountable to their respective SIRC and must abide by the policies and regulations designed and agreed upon the SIRC. Zakat centers must seek permission from the SIRC regarding certain matters. For example, a chief executive officer (CEO) of an organized and professional zakat management center sought permission to 
publish his article in an externally edited book. The CEO viewed that the publication, along with social welfare activities, contributes to knowledge dissemination and social obligation and thus strengthen the confidence of zakat payers and increase zakat collections. However, he was not given permission by the SIRC, who opined that such activity would expose their internal data, facts, and information to the public and may be a detriment to the council (Salleh, 2014).

The second obstacle is the nature of the zakat institutions' operational mechanism. The arising problems are due to the conflict of management culture by both zakat management centers and the SIRC. Zakat management centers use professional management culture, whereas the SIRC is more conservative and adopts traditional management culture. The professional management culture refers to the corporate culture adopted especially by organized and professional zakat management institutions, such as those in the States of Selangor and Penang and the Federal Territory of Malaysia. On the contrary, the traditional management culture refers to a management culture that is rather conservative and impassive, with a certain degree of unassertiveness (Salleh, 2014). The conflict between these two management cultures causes problems within a particular zakat center that may lead to the ineffectiveness of zakat institutions.

Internal control is considered as one of the crucial components for an organization to gain public trust. Internal control is a process affected by the entity's board of directors, management, and other personnel and designed to provide reasonable assurance regarding the effectiveness of operations, reliability of financial reporting, and compliance with applicable laws and regulations (COSO, 1994). An effective zakat institution needs an effective internal control to ensure that the firm's operational and financial objectives are met. Internal control must be comprehensive and involve people at all levels in a firm (Deloitte and Touche LLP, 2004). In addition, internal control must be supported by quality financial reporting, which is a credible source to measure the performance of management (Mediawati, 2016). Karim and Ahmed (1990) claimed that zakat institutions need a Shariah Supervisory Board (SSB) to ensure that institutional processes are in accordance to the Islamic law. SSB should also be involved in the accounting policies and Shariah reporting as the report can convince readers that the financial statements are according to the Islamic law.

Another attribute in developing good image as well as public perception toward an institution is its reputable members of trustees. Reputable members of trustees can convince zakat payers that contributing to a particular zakat institution is trustworthy. Considering that zakat institutions are charitable institutions involving agents, these institutions are also associated with information asymmetry. The engagement of reputable members of trustees can provide a positive signal in addition to the disclosure of audited information, feedback received from beneficiaries and donors, organizational achievement, and received government assistance (Daily \& Dalton, 2001; Handy, 2000). Mustafa et al. (2013) suggested that a board should comprise reputable members from different functional and educational backgrounds possessing the willingness and capacity to distribute zakat money according to the Shariah dictations. Zakat payers consider reputable members in the board as a positive signal of good management (Mustafa et al., 2013).

\section{Governmental Model}

Al-Qardawi (1999) argued that Islamic governments should run zakat institutions. In the case of non-Islamic governments, zakat institutions are run by private organizations that function as sole zakat fund administrators or co-exist with governmental institutions (AlQardawi, 1999; Faridi, 1990; Hasan, 2007; Kahf, 1995; Mohammad, 1990). A problem 
arises from the varying public perception regarding the effectiveness of governments and private agencies or organizations in managing zakat institutions. Numerous people view private organizations as more effective than government institutions, but others may have different opinions (Analoui, 2009). For example, Banfield (1985) asserted that governmental organizations are ineffective in reducing corruption because of strong central control. These organizations focus on the effort of mitigating corruption rather than the outcome from the effort. Similarly, governmentcontrolled agencies have many organizational goals (Dahl and Lindblom (1976). The problem is they overlook the cost of achieving these goals. In addition, governments have more "red tapes" than the private sectors, which are controlled by the market. Both views highlight the weaknesses of government agencies and institutions are rooted in management.

By contrast, Downs (1964) provided a different view on the governmental control of organizations. He argued that most organizational internal decisions are seriously influenced by the political environment. Wamsley and Zald (1973) agreed that government-owned organizations are subjected to unique public expectations. The political sentiments toward the agencies become more important than the economic output. Accordingly, zakat institutions run by the government become more acceptable to the public than those run by private organizations.

Another view suggests that both government and private ownership feature similarities in terms of management environment. Palmera and Dunford (2001) noted that managers in the private sector and commercial enterprises and government-owned organizations have similar views on the nature of their external environment. Both types of organizations show similar level of usage with regard to new organizational practices. In the context of zakat institutions, Mustafa et al. (2013) claimed that zakat payers in Bangladesh have better perceptions toward non-governmental zakat institutions than governmental ones that lead to compliance behavior. In addition, evidence in Malaysia show that during the 1980 s, farmers were reluctant to pay zakat to the government-operated zakat institutions due to past malpractices. Zakat payers perceived the government as non-Islamic during those times. Scott (1985) opined that the government should run accordingly and strictly adhere to Islamic practices (Scott, 1985). The two situations show that the zakat organizational model influences the behavior of zakat payers. Zakat payers are concerned about the ability and importance of governmental zakat institutions in determining their preferences (Mustafa et al., 2013).

Moreover, government plays an important role to encourage zakat payers to perform their duties as Muslims. Borhan and Wahab (2014) stated that the term "government" covers the fatwa, policies, and laws decided by the government. The components in a government that help to improve zakat collection are enforcement, tax incentives, ruling, and encouragement (Borhan $\&$ Wahab, 2014). For example, in the context of tax compliance, law enforcement is a main contributor to high tax compliance (Murphy, 2008). Arguably, the law enforcement can also be a significant contributor for increasing zakat compliance behavior (Saad, Idris, \& Bidin, 2009). These studies find that zakat payers consisting of businessmen believe and abide by the rules prescribed by authorities. As a result, they are willing to pay through the formal channel. However, Saad et al. (2009) found that the non-compliance attitude toward zakat regulations occur when law is not strictly enforced on zakat payers. This finding is consistent with that of Idris (2009), in which a positive relationship exists between individual perception toward law enforcement and zakat payment. The authorities should strictly enforce the zakat law in Malaysia to increase public compliance behavior in zakat payment. The existing laws should be revised and amended (Mahmood, 2007). 
Krafess (2005) claimed that many Muslims have a negative assumption that majority of the government has hidden political agendas in managing zakat institutions. Such assumption adversely affects the zakat payers' trust on charitable organizations formed by the government. As a result of zakat payers' attitude against governmental agencies and institutions, voluntary and private organizations emerge to fill the gap (Krafess, 2005). Jordan has more than 500 registered voluntary bodies, and Egypt has more than 10,000 voluntary organizations that manage zakat and other donations. As a result, these voluntary organizations compete with one another for the limited zakat and donations. Given the intense competition, zakat institutions must adopt marketing strategies to gain competitive advantage. In Malaysia, zakat institutions use promotional gifts as one of their marketing strategies. However, zakat institutions must adequately understand the factors that improve trust to ensure that they will not use unnecessary marketing strategies that misuse zakat payers' money (Wahid, Ahmad, \& Kader, 2008).

Zakat institutions rely primarily on the contributions of individual zakat payers. Zakat payers have the option to pay either directly to the asnafs or through zakat institutions who act as a third party. The latter leads to doubts as the appropriateness of zakat implementation intensifies when it is done through a third party. Zakat payers often require signals to mitigate this information asymmetry. When organizations face legitimacy problems, disclosure is one of the solutions (Suchman, 1995), which is consistent with legitimacy theory indicating that legitimacy is achieved through "internal and external audiences who observe the organization and make legitimacy assessments" (Ruef \& Scott, 1998, p. 880). Disclosure is a vehicle to either reiterate this congruence (Deegan, 2002; Ruef \& Scott, 1998) or recover legitimacy if shared beliefs appear to be disintegrating (Patten, 1992).

\section{Research Framework and Hypotheses}

Figure 1 depicts the research framework of this study. The research framework attempts to explain the relationship between the independent variables and dependent variable. In this study, the independent variables are board management and governmental model, and the dependent variable is the zakat payers' trust on zakat institutions.

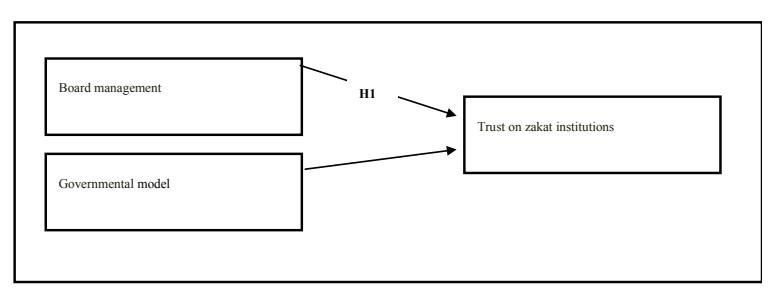

Figure 1: Research Framework

Mustafa et al. (2013) noted that board management with the right combination of members provides useful strategic advice and can link the institution to a high net worth of Muslims. Zakat payers' perception toward zakat board management's quality significantly influences the perceptions toward stakeholder management as well as disclosure practices. Based on their findings, Mustafa et al. (2013) concluded that when board management is perceived with a high quality, zakat payers favorably perceive the board management's ability to manage stakeholders and financial disclosures. That is, good management can be translated to good management practices.

When the board of a zakat institution comprises reputable members from different functional and educational backgrounds, these members are viewed as a good signal that the organization can be trusted to manage its affairs in accordance with the Shariah (Mustafa et al., 2013). Board management is the main contributor in sustaining a fruitful relationship with the external environment. Board management can enhance and create alliances with the stakeholders and controlling resources required by an institution (Wahab \& Rahman, 2011). Trust can be created when organizations are managed efficiently. The 
following hypothesis is developed:

\section{H1: A significant relationship exists between the board management of zakat institutions and trust of zakat payers.}

Perception of zakat payers toward the governmental model of zakat institutions can be explained as how zakat payers perceive the government of zakat institutions' ability and importance in managing the institution entirely (Mustafa et al., 2013). A relationship involving an agent (zakat institution) is often associated with agency problems due to information asymmetry. Government intervention is one of the means to reduce the problems related to information asymmetry. Hansmann (1981) insisted that to enjoy the benefits provided by the government (e.g., tax exemption), the government can require the registration of charity bodies. By registering with government bodies, the charitable status is subject to nondistribution constraint, a signal that can easily be observed by a donor. This signal declares that the organization is subject to certain laws and regulations that protect the donor's interests. The government will not only constrain the behavior of charities but also provide a signal that is free for the donor to observe but costly for the charity to obtain (Handy, 2000).

In the context of zakat institutions, Hasan (2007) reported that zakat payers in Bangladesh prefer to perform their obligations to non-governmental zakat institutions. To the contrary, Scott (1985) reported that zakat payers are reluctant to pay to the non-Islamic government due to trust issues. Both studies show a connection between government structure in a zakat institution and trust of zakat payers that is translated in their compliance action. The following hypothesis is developed:

\section{H2: A significant relationship exists between} the governmental model of zakat institutions and trust of zakat payers.

\section{Methodology}

Sample

Muslim individuals eligible to pay zakat on income are chosen as the sample. Zakat on income is charged on the fixed income earners regardless whether they are working in the public or private sector. For the purpose of this study, only fixed income earners located in Klang Valley, Malaysia are chosen as the sample. Five hundred and sixty seven questionnaires were distributed to possible zakat payers through personally administered questionnaires and online questionnaires. Out of the 567 questionnaires, 193 usable responses were received with an overall response rate of $32 \%$. Sekaran and Bougie (2013) claimed that the general rule to identify the sample size is more than 30 and less than 500 for any area of research. In this study, the selected sample size is 184 , which is considered appropriate.

\section{Research Instrument}

This study uses close-ended questionnaires that provide alternative choices to the respondents (Sekaran \& Bougie, 2013). The design of the questionnaire is adapted from Mustafa et al. (2013) with modifications to suit the context of this study. The questionnaire in this study consists of five sections. Section 1 requests the respondents to complete their demographic information, such as age, gender, education, and working sector.

Section 2 requests the respondents to identify their status of payment or non-payment of income tax and zakat, including whether they pay income tax, are eligible to pay zakat on income, and pay zakat on income, and if yes, the method of zakat payment. The respondents are requested to respond based on a five-point scale ranging from " 1 " as strongly disagree to "5" as strongly agree. 
Section 3 requests the respondents to provide their perception toward board management. The questions were designed to determine the perception of zakat payers toward board management. The questions include "a board of zakat institution should have members with different professional backgrounds," "the presence of a member well known for his honesty on the board of zakat is important," "having a Shariah scholar on the board of zakat institutions is helpful," and "at least, a representative of zakat payers may need to be on the board of zakat institutions." The respondents are requested to respond based on a five-point scale ranging from " 1 " as strongly disagree to "5" as strongly agree.

Section 4 contains four questions focusing on the perception toward the governmental model of zakat institutions. The questions include "government should manage zakat institution effectively," "government may add to the legitimacy of zakat institutions," and "government ownership positively influences the effectiveness of zakat board of trustees." This section also requests the respondents to identify whether the NGOs may effectively run zakat institutions in Muslim-majority countries. The respondents are requested to respond based on a five-point scale ranging from " 1 " as strongly disagree to " 5 " as strongly agree.

Finally, section 5 contains six questions requesting the respondents to identify their trust level on zakat institutions. The questions in this section include "zakat institutions should disclose financial information in the audited report," "zakat institutions should not disclose their achievements in the audited report," and "diverse professional experiences of board members may positively influence the scope of information disclosed by zakat institutions." The respondents are requested to respond based on a five-point scale ranging from " 1 " as strongly disagree to " 5 " as strongly agree.

\section{Data Collection}

Two hundred questionnaires were distributed to possible zakat payers through personally administered questionnaires and social media. Collecting the questionnaires that had been distributed took roughly a month. Ninetyeight of 107 responses received from the respondents through the personally administered questionnaires were usable. Nine questionnaires were incomplete and thus excluded.

This study also distributed 367 online questionnaires through social media, such as Facebook and WhatsApp. The message containing the questionnaire's URL address was sent through personal message as well as disseminated as public post on personal and group walls. After four weeks and several follow-ups, only 112 responses were gathered and only 86 responses were usable. Twentysix responses were excluded. An electronic questionnaire was used in this study because it is easier to administer as the data collected were automatically entered into a spreadsheet. In total, 184 respondents successfully completed the questionnaire.

\section{Results and Discussions}

\section{Zakat Payers'Profile}

Table 1 presents the distribution of respondents by tax payers and eligibility to pay zakat. The results show that majority of the respondents who are tax payers are also zakat payers, accounting for 126 respondents or $68 \%$ of all respondents. The remaining 58 respondents or $32 \%$ are not tax payers, but they are eligible to pay zakat. 
GJAT | JANUARY 2018 | SPECIAL ISSUE| 80

ISSN : 2232-0474 | E-ISSN : 2232-0482

www.gjat.my

Table 1: Tax Payers and Eligibility to Pay Zakat

\begin{tabular}{|l|c|c|c|}
\hline \multicolumn{2}{|l|}{ Eligible to pay zakat on income } & & N \\
\cline { 2 - 4 } \\
Do you pay income tax? & & Pes & 126 \\
\hline Total & & No & 58 \\
\cline { 2 - 4 } & & & 184 \\
\hline
\end{tabular}

Table 2 presents the distribution of respondents by their eligibility to pay zakat on income and zakat compliance. Majority of the respondents who are eligible to pay zakat perform their obligation as zakat payers, accounting for 137 respondents or $74.5 \%$. The remaining 47 respondents or $25.5 \%$ do not perform their obligation of paying zakat.
Table 3 presents the distribution of respondents in terms of zakat compliance and zakat payment method. Majority of the zakat payers (96 respondents or $70.1 \%$ ) choose to pay zakat through zakat centers, that is, formal institutions. Twenty-seven respondents or $19.7 \%$ choose to pay directly to asnafs. The remaining 14 respondents or $10.2 \%$ choose to pay through both formal and informal channels.

Table 2: Eligibility to Pay Zakat and Zakat Compliance

\begin{tabular}{|c|c|c|c|c|c|}
\hline & & & \multicolumn{2}{|c|}{ Zakat compliance } & \multirow[b]{3}{*}{ Total } \\
\hline \multicolumn{3}{|c|}{ Yes } & & & \\
\hline \multicolumn{3}{|c|}{ No } & & & \\
\hline \multirow[t]{4}{*}{ Eligibility to pay zakat on income } & \multirow[t]{2}{*}{ Yes } & $\mathrm{N}$ & 137 & 47 & 184 \\
\hline & & $\%$ & 74.5 & 25.5 & 100.0 \\
\hline & No & $\mathrm{N}$ & 0 & 0 & 0 \\
\hline & & $\%$ & 0.0 & 0.0 & 0.0 \\
\hline Total & & $\mathrm{N}$ & 137 & 47 & 184 \\
\hline
\end{tabular}

Table 3: Zakat Compliance and Zakat Payment Method

\begin{tabular}{|c|c|c|c|c|c|c|c|}
\hline \multirow{2}{*}{\multicolumn{3}{|c|}{ Pay direct to the zakat recipients (asnafs) }} & \multicolumn{4}{|c|}{ If yes, how do you normally pay zakat? } & \multirow{4}{*}{$\begin{array}{c}\text { Total } \\
137\end{array}$} \\
\hline & & & \multirow{3}{*}{$\begin{array}{c}\text { Both } \\
27\end{array}$} & \multirow{3}{*}{$\begin{array}{c}\text { Do not Pay } \\
96\end{array}$} & & & \\
\hline \multicolumn{3}{|c|}{ Pay through zakat centre } & & & \multirow[b]{2}{*}{14} & \multirow[b]{2}{*}{0} & \\
\hline \multirow[t]{4}{*}{ Do you pay zakat on income? } & \multirow[t]{2}{*}{ Yes } & $\mathrm{N}$ & & & & & \\
\hline & & $\%$ & $19.7 \%$ & $70.1 \%$ & $10.2 \%$ & $0.0 \%$ & $100.0 \%$ \\
\hline & \multirow[t]{2}{*}{ No } & $\mathrm{N}$ & 0 & 0 & 0 & 47 & 47 \\
\hline & & $\%$ & $0.0 \%$ & $0.0 \%$ & $0.0 \%$ & $100.0 \%$ & $100.0 \%$ \\
\hline \multirow{2}{*}{\multicolumn{2}{|c|}{ Total }} & $\mathrm{N}$ & 27 & 96 & 14 & 47 & 184 \\
\hline & & $\%$ & $14.7 \%$ & $52.2 \%$ & $7.6 \%$ & $25.5 \%$ & $100.0 \%$ \\
\hline
\end{tabular}


Effect of Board Management on Zakat Payers' Trust on Zakat Institutions

Table 4 presents the descriptive analysis of the first independent variable, that is, the perception toward the board management of zakat institutions. The highest mean score is obtained by the items coded as B1 $(\mathrm{M}=4.64$, $\mathrm{SD}=0.52)$, in which zakat payers agreed with the statement. Items B2 $(\mathrm{M}=4.54, \mathrm{SD}=0.68)$ and $\mathrm{B} 3(\mathrm{M}=4.54, \mathrm{SD}=0.63)$ follow with the same mean score. Item B4 ranks as the second lowest mean score $(\mathrm{M}=4.28, \mathrm{SD}=0.74)$. Item $\mathrm{B} 5$ has the lowest mean score $(\mathrm{M}=4.18$,
$\mathrm{SD}=0.75)$. Although B5 has the lowest mean score among other questions within the same variable, the mean score indicates a high score. Overall, all respondents agreed with all items in this variable.

Table 5 presents the results showing the relationship between perceived board management and zakat payers' trust on zakat institutions. Pearson correlation analysis was used, and the results show a significant positive relationship between board management and zakat payers' trust on zakat institutions ( $\mathrm{r}=$ $0.000)$. Hence, H1 is supported.

Table 4: Descriptive Statistics on Board Management

\begin{tabular}{|l|lcc|}
\hline \multicolumn{1}{|c|}{ Items } & \multicolumn{1}{|c|}{ Descriptions } & Mean & \multicolumn{1}{|c|}{ Std. Deviation } \\
\hline B1 & $\begin{array}{l}\text { A board of zakat institution should have members with different } \\
\text { professional backgrounds }\end{array}$ & 4.64 & 0.52 \\
\hline B2 & $\begin{array}{l}\text { The presence of a member, well known for his honesty on the } \\
\text { board of zakat institution is important }\end{array}$ & 4.54 & 0.68 \\
\hline B3 & $\begin{array}{l}\text { Having a Shariah scholar on the board of zakat institutions is } \\
\text { helpful. }\end{array}$ & 4.54 & 0.63 \\
\hline B4 & Influential people should be on the board of zakat institutions. & 4.28 \\
\hline B5 & $\begin{array}{l}\text { At least, a representative of zakat payers may need to be on the } \\
\text { board of zakat institutions. }\end{array}$ & 4.18 \\
\hline
\end{tabular}

Table 5: Correlation between Perceived Board Management and Zakat Payers' Trust on Zakat Institutions (N=184)

\begin{tabular}{|l|l|c|c|}
\hline & & Zakat payers' trust & Board Management \\
\hline Zakat Payers' Trust & Pearson correlation & 1 & 0.704 \\
& Sign (2 tailed) & & 0.000 \\
\hline
\end{tabular}


Effect of Governmental Model on Zakat Payers' Trust on Zakat Institutions

Table 6 presents the descriptive statistics of the four items of the second independent variable, that is, perception toward the governmental model of zakat institutions. The highest mean score and standard deviation are for item G1 (M $=4.47, \mathrm{SD}=0.93$ ), indicating the mean score of high scores. This item ranked first among all the items studied. Items G3 (M = 4.08, SD
$=0.96)$ and $\mathrm{G} 2(\mathrm{M}=3.84, \mathrm{SD}=1.11)$ follow. The item that obtained the lowest mean score is the last item, $\mathrm{G} 4(\mathrm{M}=3.48, \mathrm{SD}=1.26)$.

Table 7 presents the results showing the relationship between perceived governmental model and zakat payers' trust on zakat institutions. The Pearson correlation analysis was used, and the results show that the relationship is negative and insignificant ( $r=$ $0.922)$. Hence, $\mathrm{H} 2$ is rejected.

Table 6: Descriptive Statistics on Governmental Model

\begin{tabular}{|l|l|c|c|}
\hline \multicolumn{1}{|c|}{ Items } & \multicolumn{1}{|c|}{ Descriptions } & Mean & Std. Deviation \\
\hline G1 & Government should manage zakat institutions effectively. & 4.47 & 0.93 \\
\hline G2 & $\begin{array}{l}\text { NGOs may effectively run zakat institutions in Muslim-majority } \\
\text { countries. }\end{array}$ & 3.84 & 1.11 \\
\hline G3 & Government may add to the legitimacy of zakat institutions. & 4.08 & 0.96 \\
\hline G4 & $\begin{array}{l}\text { Government ownership positively influences the effectiveness of } \\
\text { board of trustees. }\end{array}$ & 3.48 & 1.26 \\
\hline
\end{tabular}

Table 7: Correlation between Perceived Board Management and Zakat Payers' Trust on Zakat Institutions

\begin{tabular}{|c|c|c|c|}
\hline & & Zakat Payers' Trust & Governmental Model \\
\hline \multirow[t]{3}{*}{ Governmental Model } & Pearson correlation & -0.007 & 1 \\
\hline & Sign (2 tailed) & 0.922 & \\
\hline & $\mathrm{N}$ & 184 & 184 \\
\hline
\end{tabular}

\begin{tabular}{lcccc} 
& Unstandardized Coefficients & Standardized Coefficients & $\mathrm{t}$ & Sig. \\
Model & $\mathrm{B}$ & Std. Error & Beta & 0.154 \\
(Constant) & 0.320 & 2.080 & .878 \\
Board Management & & & .704 & 13.338 \\
Governmental Model & 1.066 & .080 & .011 & .000 \\
\hline
\end{tabular}




\section{Additional Analysis}

A regression analysis was performed to examine the relationship between zakat payer's perceived board management and governmental model and trust. All independent and dependent variables were entered in the regression analysis. Table 8 depicts the result of the regression analysis. The results confirm the significance of the relationship between the perceived board management and governmental model on zakat payers' trust on zakat institutions. The results show significant relationship $(r=0.000)$ between the perceived board management and zakat payers' trust on zakat institutions but reflect no significant relationship between the perceived governmental model and the dependent variable.

The results in Table 8 indicates that zakat payers' trust on zakat institutions may vary due to several factors. Through the model, one predictor positively influences the unit of trust, and another predictor negatively impairs the unit of trust. The positive predictor is board management, whereas the negative predictor is governmental model.

\section{Conclusion}

This study examines the effect of board management and governmental model on zakat payers' trust on zakat institutions. The results show a significant positive relationship between perception toward zakat board management and zakat payers' trust on zakat institutions. This conclusion is consistent with the findings of Wahab and Rahman (2011) and Farber (2005). Both studies agree that board composition is the prime factor that determines the effectiveness of an institution. Certo (2003) and Daily and Dalton (2001) also discovered that due to the reputable members on a board, investors are willing to pay premium on initial public offering. In addition, Handy (2000) suggested that charitable organizations can seek reputable board members as a sign of trustworthiness. When zakat payers believe that a particular organization exercises good judgement due to the reputable board management, their level of trust may rise (Sargeant \& Lee, 2002).

Mustafa et al. (2013) pointed out the connection of reputable board management with other related factors, such as disclosure practices and stakeholder management. When zakat institutions have reputable members on board, high-quality disclosed information as well as sound stakeholder management are achieved (Mustafa et al. (2013). The board is the decision maker in strategic management, and the members utilize other resources according to their preferences. The present study also shows no significant relationship between perceived

governmental model and zakat payers' trust on zakat institutions. Such results contradict with the findings by Handy (2000), who claimed that the role of government involvement is a signal of donor and public confidence. The result of the present study is consistent with the findings of Mustafa et al. (2013). They reported that the perception toward the governmental ownership of zakat institutions does not influence trust on governmental zakat institutions.

This study is not without limitations. First, the sample in this study comprises potential zakat payers situated in one of the states in Malaysia. Future research can involve a large number of respondents comprising zakat payers from different states and countries to improve the relevancy of the findings. Future research should also conduct a comparative study regarding the factors that influence the trust on zakat centers of zakat payers from different states. Second, this study only focuses on two variables, namely, perceived board management and governmental model. Future study can include other variables in examining zakat payers' trust on zakat organizations. The findings of this study contribute to the existing body of knowledge on zakat management practices. The study assists zakat managers in achieving their objective to increase zakat collections. Managers can enhance their understanding on how to manage the institution strategically for 
improving zakat collections. The improved zakat institutions can ultimately assist the institutions to achieve zakat goals in serving beneficiaries as well as the economic objectives. According to the findings, zakat institutions should focus on how to attract zakat payers' trust in terms reputable board management. The outcome of this survey is also expected to assist policy makers in establishing zakat institutions that can be perceived legitimate by the public.

\section{Acknowledgment}

We wish to thank the Accounting Research Institute, Universiti Teknologi MARA, and Kementerian Pendidikan Tinggi for supporting and funding this study.

\section{References}

Abdul Rahman, R., Sulaiman, S., Fadel, E. S., \& Kazemian, S. (2016). Earnings Management and Fraudulent Financial Reporting: The Malaysian Story. Journal of Modern Accounting and Auditing, 12(2), 91-101.

Abdul Rahman, R., Al Smady, A., \& Kazemian, S. (2015). Sustainability of Islamic Microfinance Institutions through Community Development. International Business Research, 8(6), 196-207.

Abioyea, M.M.O., Mohamad, M.H.S.\& Adnan, M.A. (2011). Antecedents of zakat payers" trust: The case of Nigeria. International Journal of Economics, Management and Accounting, 19 (3),

Ahmad, I., \& Ma"in, M. (2014). The efficiency of zakat collection and distribution: Evidence from two stage analysis. Journal of Economic Cooperation and Development, 35(3), 133-170.

Al-Qardawi, Y. (1999). Fiqh az-zakat: A comparative study (Vol. 407). London: Dar Al-Tawwa Ltd.

Analoui, F. (2009). Challenges of successful reform: An international perspective. Journal of Management Development, 28(6), 489-494.

Banfield, E.C. (1985). Corruption as a feature of governmental organization Here the People Rule: Springer.

Bennett, R., \& Barkensjo, A. (2005). Causes and consequences of donor perceptions of the quality of the relationship marketing activities of charitable organisations. Journal of Targeting, Measurement and Analysis for Marketing, 13(2), 122-139.

Borhan, J.T., \& Wahab, A.A. (2014). Determinant factors for zakah payment by business entities in Malaysia: A theoretical review. Shariah Journal, 22(3), 295-322.

Certo, S.T. (2003). Influencing initial public offering investors with prestige: Signaling with board structures. The Academy of Management Review, 28(3), 432-446.

COSO (1994). Internal Control Integrated Framework. AICPA Publications.

Dahl, R.A., \& Lindblom, C.E. (1976). Politics, economics, and welfare, Transaction Publishers.

Daily, C.M., \& Dalton, D. (2001). Signaling firm value through board structure: An investigation of initial public offerings. Entrepreneurship Theory Practice, 26, 33-50.

Daily, C.M., Dalton, D.R., \& Rajagopalan, N. (2003). Governance through ownership: Centuries of practice, decades of research. Academy of Management Journal, 46(2), 151158.

Deegan, C. (2002). Introduction: The legitimising effect of social and environmental disclosures-a theoretical foundation. Accounting, Auditing \& Accountability Journal, 15(3), 282-311.

Deloitte \& Touche LLP. (2004). Internal control over financial reporting an investor resources. In P. K. Day (Ed.), Accountabilities: Five Public 
Services. New York: Tavistock Publications.

Doney, P.M., Cannon, J.P. (1997). An examination of the nature of trust in buyer-seller relationships. The Journal of Marketing, 35-51.

Downs, A. (1964). Inside bureaucracy: Little, Brown Boston.

Farber, D.B. (2005). Restoring trust after fraud: Does corporate governance matter?, The Accounting Review, 80(2), 539-561

Ghani, E. K., Said, J., \& Yusuf, S.N.S. (2012). Service Quality Performance Measurement Tool in Islamic Non-Profit Organisation: An Urgent Need. International Business and Management, 5(2), 71-75.

Handy, F. (2000). How we beg: The analysis of direct mail appeals. Nonprofit and Voluntary Sector Quarterly, 29(3), 439-454.

Hansmann, H.B. (1981). Reforming nonprofit corporation law [Press release]

Hasan, S. (2007). Philanthropy and social justice in Islam: Principles, prospects and practices, AS Noordeen.

Idris, K.M. (2009). Gelagat kepatuhan zakat pendapatan penggajian, Penerbit Universiti Utara Malaysia

Karim, A., \& Ahmed, R. (1990). Standard setting for the financial reporting of religious business organisations: The case of Islamic banks. Accounting and Business Research, 20(80), 299-305.

Krafess, J. (2005). The influence of the Muslim religion in humanitarian aid. International Review of the Red Cross, 87(858), 327-342.

Khandwalla, P.N. (1987). Generators of pioneering-innovative management: some Indian evidence, Organisational Studies, 8(1), 39-59
Mahmood, S. (2007). Sistem perundangan zakat di Malaysia: Antara realiti dan harapan. Zakat Law System in Malaysia: Between Reality and Expectation). Paper presented at Persidangan Zakat dan Cukai Peringkat Kebangsaan, Kuala Lumpur, 22.

Mediawati, E. (2016). Internal control and sharia supervisory board role in zakat management organisation. International Journal of Recent Advances in Multidisciplinary Research, 3(8), 1730-1732.

Meyerson, D., Weick, K.E., \& Kramer, R.M. (1996). Swift trust and temporary groups. Trust in organizations, Frontiers of Theory and Research, 166, 195.

Mohammad, I. (1990). Practical Application of zakat collection: A Case of Sudan. Paper presented at the Proceedings of 3rd International Zakah Conference, Kuala Lumpur, May.

Murphy, K. (2008). Enforcing tax compliance: to punish or persuade?, Economic analysis and policy, 38(1), 113-135.

Mustafa, M.O.A., Mohamad, M.H.S., \& Adnan, M. A. (2013). Antecedents of zakat payers" trust in an emerging zakat sector: an exploratory study. Journal of Islamic Accounting and Business Research, 4(1), 4 - 25

Nadzri, F.A.A., Rahman, R.A. \& Omar, N. (2012). Zakat and poverty alleviation: Roles of zakat institutions in Malaysia, International Journal of Arts and Commerce, 1(7), 61-72

Ong, C., \& Wan, D. (2008). Three conceptual models of board role performance: Corporate Governance, The International Journal of Business in Society, 8(3), 317-329.

Othman, M.A., Ahmad, R.A.R., \& Salleh, M.S. (2015). Assessing the satisfaction level of zakat recipients towards zakat management. Procedia Economics and Finance, 31, 140-151. 
Palmera, I., \& Dunford, R. (2001). The diffusion of managerial innovations: A comparison of Australian public and private sector take-up rates of new organisational practices. International Public Management Journal (4), 49-64.

Patten, D.M. (1992). Intra-industry environmental disclosures in response to the Alaskan oil spill: A note on legitimacy theory,. Accounting, Organisations and Society, 17(5), 471-475.

Rahim, S., \& Kaswadi, H. (2014, 1-2 December 2014). An economic research on zakat compliance among Muslim"s staff in UNIMAS. Paper presented at the Proceeding of the International Conference on Masjid, Zakat and Waqf (IMAF 2014), Kuala Lumpur, Malaysia.

Rahman, A.A., Alias, M.H., \& Omar, S.M.N.S. (2012). Zakat institution in Malaysia: Problems and issues. Global Journal of Al-Thalaqah, 2, $35-42$.

Ruef, M., \& Scott, W.R. (1998). A multidimensional model of organizational legitimacy: Hospital survival in changing institutional environments. Administrative Science Quarterly, 877-904.

Saad, R.A.J., Idris, K.M., \& Bidin, Z. (2009). Peraturan pembayaran zakat kepada institusi zakat: sikap peniaga dan kesannya terhadap gelagat pembayaran zakat perniagaan. Jurnal Syariah, 17(3), 607-630.

Salleh, M.S. (2014). Organisational and defitional reconfiguration of zakat management. International Journal of Education and Research, 2 (5).
Sargeant, A., \& Lee, S. (2002). Improving public trust in the voluntary sector: An empirical analysis. International Journal of Nonprofit and Voluntary Sector Marketing, 7(1), 68-83.

Sekaran, U., \& Bougie, R. (2013). Research methods for business: A skill building approach (6th ed.): Business \& Management.

Scott, J. (1985). Weapons of the Week: New Haven, Yale University Press.

Suchman, M.C. (1995). Managing legitimacy: Strategic and institutional approaches. Academy of management review, 20(3), 571-610.

Wahab, N.A., \& Rahman, A.R.A. (2011). A framework to analyse the efficiency and governance of zakat institution. Journal of Islamic Accounting and Business Research, 2(1), 43-62.

Wahid, H., Ahmad, S., \& Kader, R.A. (2008). Pengagihan zakat oleh institusi zakat di Malaysia: mengapa masyarakat Islam tidak berpuas hati? Paper presented at the Proceedings of Seminar Kebangsaan Ekonomi Malaysia.

Wamsley, G.L., \& Zald, M.N. (1973). The political economy of public organizations, Public Administration Review, 33(1), 62-73.

Zahra, S.A., \& Pearce, J.A. (1989). Boards of directors and corporate financial performance: A review and integrative model. Journal of management, 15(2), 291-334. 